\title{
Polyunsaturated fatty acids in reducing cardiovascular risk
}

\author{
Wielonienasycone kwasy tłuszczowe w redukcji ryzyka sercowo-naczyniowego
}

\author{
Department of Internal Medicine and Clinical Pharmacology, Medical University of Silesia in Katowice, Katowice, Poland \\ Correspondence: Maciej Kołodziejzzyk, Department of Internal Medicine and Clinical Pharmacology, Medyków 18, 40-752 Katowice, Poland, e-mail: mackolodziejzzyk07@gmail.com
}

\begin{abstract}
Cardiovascular diseases are the leading cause of mortality worldwide. Prevention, diagnosis and treatment of these diseases are one of the major challenges in modern medicine. Despite a large number of pharmacological agents significantly reducing the cardiovascular risk, it is still high in many patients. Due to the multifactorial aetiology and complex pathomechanism of cardiovascular diseases, the development of a more effective therapy remains an open issue. It was found in the 1980s that a diet rich in polyunsaturated fatty acids, eicosapentaenoic acid and docosahexaenoic acid in particular, was associated with a lower incidence of cardiovascular diseases. For this reason, polyunsaturated fatty acids have become the subject of many clinical trials aimed at understanding their mechanism of action and determining their exact impact on cardiovascular risk. Polyunsaturated fatty acids are known to affect many aspects that are key factors in the development of cardiovascular disease. They are characterised mainly by a positive effect on the structure and functioning of cell membranes, the ability to reduce inflammation and blood pressure, anticoagulant and antiplatelet effects, antiarrhythmic activity, the ability to improve myocardial contractility and a beneficial effect on the lipid profile. The latest analyses of the available clinical trials show that these compounds reduce cardiovascular risk in both primary and secondary prevention. Therefore, they represent a promising therapeutic option. It is worth noting that the effect seems to depend on the type of polyunsaturated fatty acids, their dose and individual factors. Nevertheless, this issue is extremely complex and requires further research to fully understand the mechanism of action and establish ideal therapeutic doses to improve patient prognosis.
\end{abstract}

Keywords: polyunsaturated fatty acids (PUFAs), eicosapentaenoic acid (EPA), docosahexaenoic acid (DHA), cardiovascular disease (CVD)

Streszczenie Choroby układu sercowo-naczyniowego stanowią najczęstszą przyczynę zgonów na całym świecie. Ich prewencja, rozpoznawanie oraz leczenie stanowią jedno z największych wyzwań współczesnej medycyny. Mimo że istnieje liczna grupa leków, które znacznie zmniejszają ryzyko sercowo-naczyniowe, u wielu pacjentów wciąż jest ono na wysokim poziomie. Ze względu na wieloczynnikową etiologię i złożony patomechanizm chorób układu sercowo-naczyniowego kwestia opracowywania coraz bardziej skutecznej ich terapii pozostaje otwarta. W latach 80 . XX wieku zaobserwowano, że dieta bogata w wielonienasycone kwasy tłuszczowe, szczególnie kwas eikozapentaenowy oraz kwas dokozaheksaenowy, wiąże się z mniejszą częstością występowania chorób układu sercowo-naczyniowego. $Z$ tego powodu wielonienasycone kwasy tłuszczowe zaczęły stanowić przedmiot wielu badań klinicznych dążących do poznania mechanizmu ich działania oraz określenia ich dokładnego wpływu na ryzyko sercowo-naczyniowe. Obecnie wiadomo, że wielonienasycone kwasy tłuszczowe oddziałują na liczne aspekty stanowiące kluczowe czynniki rozwoju chorób układu sercowo-naczyniowego. Charakteryzują się przede wszystkim: pozytywnym wpływem na budowę oraz funkcjonowanie błon komórkowych, zdolnością zmniejszania stanu zapalnego oraz obniżania ciśnienia tętniczego, działaniem przeciwzakrzepowym i przeciwpłytkowym, działaniem antyarytmicznym, zdolnością poprawy kurczliwości mięśnia sercowego oraz korzystnym wpływem na profil lipidowy. Z najnowszych analiz dotychczas dostępnych badań klinicznych wynika, że obniżają one ryzyko sercowo-naczyniowe w prewencji zarówno pierwotnej, jak i wtórnej. W związku z tym stanowią obiecującą opcję terapeutyczną. Warto podkreślić, że efekt działania wydaje się zależeć od typu przyjmowanych wielonienasyconych kwasów tłuszczowych, ich dawki oraz czynników indywidualnych. Niemniej jednak zagadnienie to jest niezwykle złożone i wymaga dalszych badań w celu dokładnego poznania mechanizmu działania i określenia idealnych dawek leczniczych mogących poprawić rokowanie pacjentów.

Słowa kluczowe: wielonienasycone kwasy tłuszczowe (PUFAs), kwas eikozapentaenowy (EPA), kwas dokozaheksaenowy (DHA), choroby układu sercowo-naczyniowego (CVD) 


\section{INTRODUCTION}

$\mathrm{F}$ or many years cardiovascular diseases (CVDs) have been the leading cause of mortality worldwide. Despite the slow, yet gradual drop in cardiovascular mortality (especially in highly developed countries), they still lead in the statistics. Furthermore, the incidence of CVDs is constantly increasing, which is mainly due to the aging of the population, changes in the diet (increasing consumption of highly processed foods, foods rich in simple sugars and saturated fatty acids), and a sedentary lifestyle. All these elements lead to accumulation of risk factors, which in turn increases the cardiovascular risk $^{(1)}$. Despite the use of drugs with evidence-based efficacy [e.g. statins, subtilisin/kexin 9 inhibitors (proprotein convertase subtilisin/kexin 9, PCSK9)], there is still a trend towards a higher risk of cardiovascular events in these patients compared to the general population. This phenomenon is referred to as the residual risk ${ }^{(2)}$. For this reason, there is ongoing global search for new therapeutic agents that could further contribute to reduced cardiovascular mortality in both primary and secondary prevention. Polyunsaturated fatty acids (PUFAs) are one of these promising compounds.

The interest in the influence of PUFAs on the cardiovascular risk began in the 1980s, when a much lower rates of CVDs were observed among the Greenland Inuit compared to Danes. There have been many studies on the differences in the diet of both populations, based on which the researchers concluded that this phenomenon was most influenced by the significantly higher intake of PUFAs, eicosapentaenoic acid (EPA) and docosahexaenoic acid (DHA) in particular. Also, the ratio of dietary omega-3/omega-6 fatty acids was significantly higher among Inuits compared to Danes ${ }^{(3)}$. Since then, many studies have been conducted to understand the mechanism of action and the impact of PUFAs on the course and prevalence of a wide variety of diseases, including CVDs and the related cardiovascular risk, which is the focus of this paper.

The current guidelines of the European Society of Cardiology and the European Atherosclerosis Society (ESC/EAS) for the management of dyslipidaemias recommend the use of omega-3 fatty acids (icosapent ethyl) in patients at high or very high cardiovascular risk, with triglyceride (TG) levels from 1.5 to $5.6 \mathrm{mmol} / \mathrm{L}$ $(135-499 \mathrm{mg} / \mathrm{dL})$, at a dose of $2 \times 2 \mathrm{~g} /$ day in combination with statins ${ }^{(4)}$.

\section{CHEMICAL STRUCTURE AND CLASSIFICATION OF POLYUNSATURATED FATTY ACIDS}

Fatty acids are chemical compounds consisting of a hydrocarbon chain terminating in a carboxyl group other end. They are divided into saturated and unsaturated fatty acids. The difference between these two groups is that only single bonds are present between carbon atoms in saturated fatty acids, whereas unsaturated fatty acids have at least one double bond between carbon atoms. PUFAs contain more than one double bond, and the designations omega- 3 and omega- 6 indicate that the first double bond of the hydrocarbon chain is at the third and sixth carbon atoms from the terminal methyl group $\left(-\mathrm{CH}_{3}\right)$, respectively, whose carbon atom is referred to as "omega," " $\omega$ " or "n." The group of n-3 PUFAs includes a-linolenic acid (ALA; found mainly in vegetable oils), EPA and DHA (found mainly in fish oil). The group of n-6 PUFAs includes linoleic acid (LA; found mainly in vegetable oils) and arachidonic acid (AA; synthesized in our body from LA). These two groups of compounds are essential components of the diet of every human being as they cannot be synthesized de novo in the body. It should also be noted here that a phenomenon of geometric isomerism, i.e. arrangement of atoms and groups of atoms in the space around the double bond in a given molecule, is observed in unsaturated fatty acids. Therefore, they can be in the cis configuration where the acyl chains face each other, or in the trans configuration where the acyl chains are oriented in opposite directions. Most of the naturally occurring unsaturated fatty acids are cis-forms, while the unsaturated trans fatty acids in our diet are mainly by-products of fatty acid saturation in the food industry, and only some are derived from ruminant fats. Their consumption has a proven harmful effect on health and is associated with an increased risk of many diseases, including CVDs and diabetes mellitus $^{(5)}$ (Fig. 1).

\section{METABOLISM OF POLYUNSATURATED FATTY ACIDS}

For a better understanding of the subject, it is necessary to learn about the main pathways of PUFA metabolic changes that take place in our body. Both groups of polyunsaturated fatty acids are metabolised by the same enzymes belonging to groups such as lipoxygenases (LOX), cyclooxygenases (COX) and cytochrome P450 (CYP). Hormone-like compounds, known as eicosanoids, which include prostaglandins, prostacyclins, thromboxanes and leukotrienes, as well as mediators that suppress inflammation, such as lipoxins, resolvins, maresins and protectins, are the end products of these metabolic transformations. LA is mainly transformed into AA, which undergoes further transformations to prostaglandins and type 2 thromboxanes, type 4 lipoxins and leukotrienes. ALA is converted into EPA, followed by DHA. EPA is transformed into prostaglandins and type 3 thromboxanes, type 5 lipoxins and resolvins, whereas DHA is converted into resolvins, maresins and protectins ${ }^{(6)}$. It should be noted that, despite the degree of converting ALA into EPA and DHA, 
<smiles>CCCCCCCCCCCCCCCC(=O)O</smiles>
Palmitic acid, (16 - saturated fatty acid
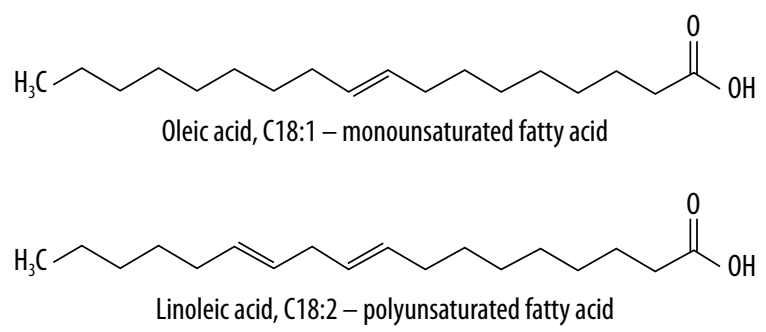

Fig. 1. Examples offatty acid formulas: palmitic acid - saturated, oleic acid - monounsaturated, linoleic acid - polyunsaturated ${ }^{(5)}$

this ability seems to be limited in humans, which means that the selective intake of large amounts of ALA (derived from vegetable oils, e.g. linseed oil or rapeseed oil) will not translate into a significant increase in the content of EPA and DHA in our body ${ }^{(7)}$.

\section{DIETARY OMEGA-6/OMEGA-3 RATIO}

The omega- 6 to omega- 3 ratio in the diet is very important for the proper functioning of the human body. Due to the changing eating habits over the years, this ratio has increased from about 1:1 in the diet of our ancestors to as much as 15-16.7:1 in Western diets. Increased intake of n- 6 PUFAs is associated with predominant thrombotic, vasoconstrictive and inflammatory processes, which promotes the pathogenesis of many chronic diseases, such as CVDs, cancer or autoimmune diseases, e.g. asthma ${ }^{(8)}$. This is mainly the result of changes in the production profile of pro-inflammatory mediators and regulators as well as proinflammatory immune response ${ }^{(9)}$. An increase in this ratio can also lead to weight gain and even obesity, which is known to be an independent risk factor for $\mathrm{CVDs}^{(10)}$. The dietary n-6 to n-3 ratio of 3-4:1 may protect against many chronic diseases in the pathogenesis of which the major role is played by unhealthy diet; therefore, it seems that this or lower ratio will be optimal for the body ${ }^{(8)}$. The form of ingested omega- 3 fatty acids (in a pure form or as ethyl esters) and the ratio of specific fatty acids are also important; therefore, clinical trials are focused on various combinations of these compounds.

\section{MULTIDIRECTIONAL MECHANISM OF ACTION OF POLYUNSATURATED FATTY ACIDS}

Polyunsaturated fatty acids:

- have a positive effect on the structure and functioning of cell membranes;

- reduce inflammation;

- reduce blood pressure;
- have anticoagulant and antiplatelet properties;

- show antiarrhythmic activity;

- improve myocardial contractility;

- improve the lipid profile.

\section{Positive effect on the cell membrane functions}

Proper breakdown of lipids in cell membranes is a key element of their normal functioning. They contain heterogeneous structures called domains, such as lipid rafts and caveolae. Modifications in their composition may have different effects on receptor activity and signalling pathways mediating such processes as e.g. endothelial function, smooth muscle cell migration, cytokine production, metabolism or migration and adhesion of inflammatory cells. Cholesterol, which excess amounts and participation in the formation of cholesterol crystal domains may disturb homeostasis, is a very important component of cell membranes. These domains are typical of cell membranes that are components of atherosclerotic plaques. EPA and DHA probably have different effects on the structural features of cell membranes. In model membranes, DHA had no effect on membrane thickness, but induced cholesterol domains and increased membrane fluidity. By contrast, EPA increased membrane thickness and inhibited cholesterol domain formation, without effects on membrane fluidity. It was also noted that the effects were dose-dependent. The data suggests that EPA may show direct atheroprotective effects. However, this issue has not been clarified and requires further research for verification and in-depth analysis ${ }^{(11,12)}$.

\section{Anti-inflammatory effects}

Mild systemic inflammation is one of the factors that play a role in the pathophysiology of atherosclerosis ${ }^{(13)}$. An inflammation-reducing therapy has been shown to significantly lower the risk of ischaemic events ${ }^{(14)}$. As a result of increased dietary intake of EPA and DHA, these two compounds partially replace the omega- 6 fatty acids, AA in particular, probably in the membranes of all cells, but especially in the membranes of thrombocytes, red blood cells, neutrophils, monocytes, and hepatocytes ${ }^{(10)}$. It also reduces blood AA levels ${ }^{(7)}$. EPA competes with AA as a product for further metabolic transformations. A shift in these transformations towards increased metabolism of EPA results in the formation of metabolites with lower inflammatory and chemotactic potential ${ }^{(15)}$. Additionally, further metabolic transformations of EPA and DHA generate the already mentioned resolvins, maresins and protectins, which promote active quenching of inflammatory reactions. They strongly reduce inflammatory signalling, mainly mediated by chemokines and cytokines. They also accelerate the removal of inflammatory cells through increased efferocytosis, and reduce the interaction of 
endothelium with leukocytes ${ }^{(16)}$. Additionally, signalling pathways associated with the peroxisome proliferator-activated receptor $\gamma$ (PPAR- $\gamma$ ) and the toll-like receptor 4 (TLR4) are modified in adipose tissue, resulting in reduced production of inflammatory mediators in this tissue. The influx of macrophages to adipose tissue is also limited ${ }^{(17)}$. Additionally, there is an increase in serum interleukin 10 (IL-10) and its production by monocytes. Reduced IL-10 levels are observed in obese individuals with dyslipidaemia. It reduces the production of pro-inflammatory cytokines and contributes to an increase in the number of monocytes/macrophages with the M2 (anti-inflammatory) phenotype compared to M1 (pro-inflammatory), which has a beneficial effect on inflammation and improves sensitivity to insulin ${ }^{(18)}$. All this leads to a decrease in serum levels of inflammatory markers, such as high-sensitivity C-reactive protein (hsCRP), tumour necrosis factor $\alpha$ (TNF- $\alpha$ ), IL-6 or IL-1 $\beta(19,20)$. Longterm use of PUFAs may also reduce chemotaxis of both monocytes and neutrophils ${ }^{(21)}$. Omega-3 fatty acids also reduce the production of endothelial adhesion molecules, such as e.g. vascular cell adhesion molecule 1 (VCAM-1), which reduces the adhesion and transmigration of leukocytes and monocytes, which are known to be involved in the pathophysiology of atherosclerotic plaque, through the endothelium ${ }^{(22)}$.

\section{Reduction of blood pressure}

Since hypertension is one of the strongest risk factors for cardiovascular diseases, it is an important target of therapy in both primary and secondary prevention ${ }^{(23)}$. A diet rich in n-3 fatty acids may slightly, yet statistically significantly reduce systolic and diastolic blood pressure. This effect is more pronounced in hypertensive patients. One of the larger meta-analyses has shown that the mean reduction in systolic and diastolic blood pressure in hypertensive patients was $4.5 \mathrm{~mm} \mathrm{Hg}$ [ $95 \%$ confidence interval (CI) 2.8-6.1] and $3.0 \mathrm{~mm} \mathrm{Hg}$ (95\% CI 1.7-4.3), respectively, compared to $1.2 \mathrm{~mm} \mathrm{Hg}$ (95\% CI 0.5-2.0) and $0.6 \mathrm{~mm} \mathrm{Hg}$ (95\% CI 0.0-1.2), respectively, in non-hypertensive patients. The inter-individual variability of this phenomenon has also been noted. The mechanism of this action involves increased NO synthesis, reduced vasoconstrictive response to noradrenaline and angiotensin II, improved vasodilatory response and arterial wall compliance, decreased activity of angiotensin converting enzyme (ACE) and activation of the vagus nerve $e^{(24,25)}$.

\section{Anticoagulant and antiplatelet effect}

The overactivation of platelets can result in the formation of blood clots, which are the underlying cause of thromboembolic events such as heart attacks and strokes ${ }^{(13)}$. Omega-3 fatty acids can reduce their progression rate and fatty acids, attention was drawn to a significantly higher bleeding and haemorrhage tendency in Greenland Inuits. Therefore, a suspicion was raised that an antithrombotic and/or antiplatelet effect may be one of the effects of omega-3 fatty acids. This action would be achieved by reduced synthesis of thromboxane A2 (a strong vasoconstrictor molecule that promotes platelet aggregation) and increased production of thromboxane A3 (a molecule with weaker prothrombotic properties than thromboxane A2), inhibition of metabolic pathways leading to platelet activation and aggregation, or diminished activation and/or levels of the inhibitor plasminogen activator inhibitor 1 (PAI-1). It was also observed that high dietary intake of EPA and DHA limit platelet aggregation around the periphery of the thrombus, which may reduce its final size, and thus the extent of ischaemia. However, the exact mechanism underlying the anticoagulant and antiplatelet action of EPA and DHA has not been fully explained, and the effect itself also remains unclear ${ }^{(26)}$. Another study has shown that high doses of EPA and DHA do not contribute significantly to increased adverse effects such as bleeding despite their demonstrated anticoagulant effects ${ }^{(27)}$. It has also been shown that the introduction of PUFAs into dual antiplatelet therapy with acetylsalicylic acid and clopidogrel in patients after percutaneous coronary intervention significantly enhanced platelet response to clopidogrel. This was evidenced by $22.2 \%$ reduction in the platelet reactivity index (PRI) $(p=0.020)$ after one month of therapy in the group receiving additional n-3 PUFAs at a dose of $1 \mathrm{~g}$ (including $460 \mathrm{mg}$ of EPA and $360 \mathrm{mg}$ of DHA) per day compared to the placebo group ${ }^{(28)}$.

\section{Antiarrhythmic effect and improved myocardial contractility}

Arrhythmias are well-known to be much more common in individuals with signs of myocardial ischaemia. They often lead to life-threatening conditions. Furthermore, arrhythmias are the most common complication of myocardial infarction (MI) (up to $60-80 \%$ of patients) ${ }^{(13)}$. At the periphery of the ischaemic zone, myocytes may be only partially depolarised. As a result, a low intensity stimulus can trigger an action potential that may spread and cause arrhythmia. n-3 PUFAs stabilise this myocytic overactivity. This occurs mainly by inhibiting voltagegated sodium channels and L-type calcium channels, which results in increased refractory time, increased strength of the threshold stimulus needed to induce an action potential, and preventing abnormally high levels of calcium ions in the cytoplasm ${ }^{(29)}$. Additionally, n-3 PUFAs increase the activity of the vagus nerve, which, by inhibiting the cardiac muscle cells, may reduce the risk of arrhythmia ${ }^{(30)}$. There are also reports on the beneficial effects of n-3 PUFAs increase on left ventricular contractile function. This effect is most likely due to a reduction in low-grade systemic inflammatory response, 
vasodilation, and a direct increase in mitochondrial consumption of oxygen. Importantly, one study showed that the increase in this effect was dose-dependent. After 3 months of exposure to a combination of EPA and DHA at $1 \mathrm{~g} /$ day, there was a mean increase of $24 \% \pm 8 \%$ to $27 \% \pm 8 \%(p=0.005)$ in ejection fraction, and the same values increased from $24 \% \pm 7 \%$ to $29 \% \pm 8 \%(p=0.02)$ after a daily dose of EPA and DHA of $4 \mathrm{~g}^{(31,32)}$.

\section{Reducing serum triglycerides}

Over the years, it has been observed in many studies that patients with elevated blood triglycerides are at an increased risk of thromboembolic events ${ }^{(33)}$. Cardiovascular risk is also increased in patients with hypertriglyceridemia who are on statins, even when other agents, such as fibrates, niacin, or cholesterol ester transfer protein (CETP) inhibitors, are included. Due to their triglyceride-lowering activity, omega-3 fatty acids are currently the subject of studies to assess their efficacy in cardiovascular diseases ${ }^{(34)}$. Many studies have shown that omega-3 fatty acids significantly reduce (even by more than $30 \%$ in some studies) blood triglycerides in a dose-dependent manner. It has also been shown that the effect is more pronounced in patients with higher baseline serum triglyceride levels ${ }^{(35,36)}$. The mechanism underlying this effect involves reduction of hepatic lipogenesis by inhibiting the expression of sterol regulatory elementbinding protein 1 (SREBP-1), which is responsible for increasing the production of enzymes that promote hepatic synthesis of cholesterol, fatty acids and triglycerides. The beta-oxidation of fatty acids is increased, thereby reducing the amount of substrates that can be used for the production of triglycerides, which are the main component of very low-density lipoprotein (VLDL) cholesterol particles produced in hepatocytes. Key enzymes in the hepatic synthesis of triglycerides, such as phosphatidic acid phosphatase and diacylglycerol acyltransferase, are inhibited. Increased expression of lipoprotein lipase (LPL), which acts by removing triglycerides from circulating VLDL cholesterol particles and chylomicrons, has also been demonstrated. Also, a decreased expression of apolipoprotein C-III has been noted. This protein, when bound to the surface of VLDL and low-density lipoprotein (LDL) cholesterol, inhibits the activity of LPL, thereby reducing the breakdown of triglycerides and the rate of their elimination from plasma ${ }^{(37)}$.

\section{Effects on cholesterol-rich lipoproteins}

It is well known that increased LDL cholesterol and decreased high-density lipoprotein (HDL) cholesterol in the blood are associated with an increased cardiovascular risk ${ }^{(13)}$. A review of studies on the effects of omega-3 fatty acids on the levels of LDL cholesterol and other blood lipids showed that in most studies DHA slightly increased LDL cholesterol (a mean of $+2.6 \%, p<0.05$ ), while EPA did not change or slightly reduced these levels (a mean of $-0.7 \%, p<0.05$ ). In turn, both EPA and DHA increased blood HDL cholesterol (EPA: $+1.4 \%$, DHA: $+7.3 \%, p<0.05)$. It is worth noting that these values were higher for DHA supplementation ${ }^{(38)}$. The mechanism of these changes in the composition of LDL and HDL cholesterol is not fully understood, but perhaps the most important factor is the increased expression of apolipoprotein A-I, which plays a key role in the maturation and proper functioning of HDL particles. Additionally, apolipoprotein A-I is also known to stabilise the metabolic activity of paraoxonase-1. This enzyme, in turn, prevents the oxidation of LDL, detoxifies oxidized LDL, inhibits their uptake by macrophages and reduces oxidative stress ${ }^{(39)}$.

\section{CLINICAL TRIALS}

Some meta-analyses of observational studies suggest that high intake of fish, and therefore omega-3 fatty acids, is associated with reduced mortality, including mortality related to thromboembolic events ${ }^{(40)}$. Some of these studies indicate that $15 \mathrm{~g}$ of fish a day can already reduce cardiovascular risk. Naturally, this also depends on other diet components, gender and calorie intake ${ }^{(41)}$. On the other hand, some analyses have shown that this impact is debatable and that there are endpoint discrepancies in these observations. There are also regionspecific differences in responses to this type of diet. Therefore, more research is needed to accurately determine these relationships ${ }^{(42)}$.

\section{Interventional studies}

A multicentre open-label GISSI-Prevenzione trial in 11,324 patients with a history of MI in the past 3 months were randomly assigned omega- 3 fatty acids ( 1 g daily, a capsule containing about 850-882 $\mathrm{mg}$ EPA and DHA at $1: 2, n=2,836)$, vitamin $\mathrm{E}$ (300 $\mathrm{mg}$ daily, $n=2,830)$, both ( $n=2,830$ ), or none (control, $n=2,828$ ). The aim of the study was to assess the effects of omega- 3 fatty acids and vitamin $\mathrm{E}$ on the prognosis in patients who survived MI. The follow-up was 3.5 years. It was found that supplementation with n-3 PUFA at higher daily doses reduced the risk of cardiovascular death by up to $20 \%$ in secondary prevention $(p=0.008)^{(43)}$.

A multicentre, randomised, double-blind, placebo-controlled GISSI-HF study assessed the effects of $n-3$ polyunsaturated fatty acids in patients with chronic heart failure. Patients diagnosed with New York Heart Association classes II to IV heart failure with left ventricular ejection fraction (LVEF) measured in the last 3 months were qualified for the study and were randomly allocated to treatment with n-3 polyunsaturated fatty acids ( 1 g daily, a capsule containing 850-882 mg EPA and 
DHA at $1: 2, n=3,494)$ or placebo $(n=3,481)$. The patients were followed for a mean of 3.9 years. It was shown that supplementation with n-3 PUFA is associated, though to a very small extent, with a lower risk of cardiovascular-related death and hospital admissions $-57 \%$ of patients on n-3 PUFAs vs. $59 \%$ of patients on placebo [relative risk $(\mathrm{RR})=0.92 ; 95 \%$ CI $0.849-0.999]^{(44)}$.

Another multicentre, double-blind, placebo-controlled trial randomly enrolled 4,837 MI survivors aged 60 to 80 years, who were on antihypertensives, anticoagulants and lipid-modifying drugs. Its aim was to investigate the effects of omega- 3 fatty acids on the incidence of thromboembolic events in MI survivors. For 40 months they received one of four supplemented margarines with a targeted additional daily intake of $400 \mathrm{mg}$ of n-3 PUFA (EPA/DHA 3:2) daily ( $n=1,192), 2 \mathrm{~g}$ of ALA daily ( $n=1,197), 400 \mathrm{mg}$ of $\mathrm{n}-3$ PUFA (EPA/DHA 3:2), and $2 \mathrm{~g}$ of ALA daily $(n=1,212)$ or a placebo margarine $(n=1,236)$. The primary endpoint was the rate of fatal or nonfatal major cardiovascular events and cardiac interventions. The study showed that supplementation with EPA/DHA (RR 1.01 ; 95\% CI 0.87-1.17) or ALA (RR 0.91; 95\% CI 0.78-1.05) did not significantly reduce the rate of these events ${ }^{(45)}$.

Another randomised, double-blind study assessed the effects of omega- 3 fatty acids ( $1 \mathrm{~g}$ daily, a capsule containing $465 \mathrm{mg}$ EPA and $375 \mathrm{mg}$ DHA) on the cardiovascular risk compared to placebo. Cardiovascular mortality was the primary endpoint. The study randomly enrolled $12,536 \mathrm{pa}-$ tients with a high cardiovascular risk and abnormal fasting blood glucose, abnormal glucose tolerance or diabetes mellitus. During a mean follow-up of 6.2 years, no significant reduction in cardiovascular risk was found in the group receiving omega-3 fatty acids compared to the placebo group: $9.1 \%$ vs. $9.3 \%$, respectively (RR $0.98 ; 95 \%$ CI $0.87-1.10)^{(46)}$. Another randomised, placebo-controlled study assessed the effects of supplementation with vitamin D (2,000 IU daily) and omega- 3 fatty acids ( 1 g daily, a capsule containing $840 \mathrm{mg}$ of omega-3 fatty acids, including $460 \mathrm{mg}$ EPA and $380 \mathrm{mg}$ DHA) in the primary prevention of CVDs and malignancies in men aged $\geq 50$ years and women aged $\geq 55$ years. A total of 25,871 patients were followed for a mean of 5.3 years. Myocardial infarction, stroke, cardiovascular death or any invasive cancer were the primary endpoints. However, the study showed no beneficial effects of omega-3 fatty acids on the risk of cardiovascular incidents (RR 0.92; $95 \%$ CI $0.80-1.06)^{(47)}$.

A randomised, open-label JELIS study was one of the studies that showed more beneficial effects of omega-3 fatty acids on the cardiovascular risk. The study enrolled 18,645 patients with total cholesterol $\geq 6.5 \mathrm{mmol} / \mathrm{L}$. The patients were randomised into two groups to receive either $1,800 \mathrm{mg}$ $\mathrm{EPA} /$ day + statin $(n=9,326)$, or statin alone $(n=9,319)$. The primary endpoint was any serious cardiovascular event, including sudden cardiac death, fatal or nonfatal MI, and coronary stenting or bypass surgery. A 19\% EPA-related reduction ( $p=0.001)$ was observed in the rates of all abovementioned serious cardiovascular incidence. A statistically insignificant $18 \%$ reduction $(p=0.132)$ was reported in the subgroup of primary prevention compared to $19 \%$ reduction $(p=0.048)$ in the subgroup of secondary prevention ${ }^{(48)}$. A multicentre, randomised, double-blind, placebo-controlled REDUCE-IT trial was a breakthrough study assessing the effects and the possible therapeutic use of omega-3 acids (EPA in particular). The study enrolled 8,179 patients with established CVD or diabetes mellitus and other risk factors, with well-controlled LDL cholesterol on statins and elevated baseline triglycerides. The participants were randomised into two groups to receive EPA at $2 \mathrm{~g}$ daily or placebo. The primary endpoints were cardiovascular death, nonfatal MI, nonfatal stroke, coronary revascularisation or unstable angina. The mean follow-up was 4.9 years. In the EPA group, the risk of reaching the primary endpoint in the time-to-event analysis was $25 \%$ lower compared with placebo, corresponding to an absolute difference of $4.8 \%$ between the groups $-17.2 \%$ of patients on EPA vs. $22 \%$ of patients in the placebo group (RR $0.75 ; 95 \%$ CI $0.68-0.83$ ). It is also worth noting that the beneficial effects of EPA did not start to appear until after about a year of follow-up, which can be inferred from the Kaplan-Meier curves showing the incidence of cardiovascular events. A clear separation of these curves took place only after 2 years of EPA administration, which indicates that some time must pass to achieve a positive effect of EPA administration ${ }^{(49)}$ (Tab. 1).

As can be seen, the effectiveness of omega- 3 fatty acids in reducing cardiovascular risk has not been clearly established in these studies. Although several studies demonstrated their positive effect, most of them showed no influence on the cardiovascular risk. The data from metaanalyses are also divergent. Two meta-analyses showed no or little effect ${ }^{(50,51)}$. In contrast, one of the more recent metaanalyses (October 2019) found that omega-3 fatty acids reduce cardiovascular risk, which may be related to the analysis of more recent studies showing the benefits of omega-3 fatty acids. This meta-analysis also noted that there appears to be a linear dose-response relationship between omega-3 fatty acids and reduced cardiovascular risk ${ }^{(52)}$. Perhaps the ingested dose in most older studies, which was often about $1 \mathrm{~g}$ per day, was too low for the full multifactorial effects of omega-3 fatty acids on our body. Involvement of other environmental or even genetic factors is also possible. However, further research is needed to explain this issue. It is also worth paying attention to the fact of using various preparations of omega- 3 fatty acids, such as their mixtures, pure forms or esters, which could also have a significant impact on the final results of analyses.

\section{CONCLUSIONS}

Despite many clinical studies on the effects of omega- 3 fatty acids on cardiovascular risk, the issue has not been fully 


\begin{tabular}{|c|c|c|c|c|}
\hline Trial & Patients & Intervention & Endpoints & Effects on endpoints \\
\hline $\begin{array}{l}\text { Dietary supplementation with } \\
\mathrm{n} \text {-3 polyunsaturated fatty acids } \\
\text { and vitamin } \mathrm{E} \text { after myocardial } \\
\text { infarction: results of the } \\
\text { GISSI-Prevenzione trial|(43) }\end{array}$ & $\begin{array}{l}\text { 11,324 patients surviving recent } \\
\text { ( } \leq 3 \text { months) MI }\end{array}$ & $\begin{array}{c}\text { Supplementation with n-3 PUFA } \\
\text { ( } 1 \mathrm{~g} \text { daily, a capsule containing } \\
850-882 \mathrm{mg} \text { EPA and DHA at } \\
1: 2 \text {, vitamin } \mathrm{E} \text { ( } 300 \mathrm{mg} \text { daily), } \\
\text { both or none }\end{array}$ & $\begin{array}{l}\text { Cardiovascular death, nonfatal } \\
\text { MI, nonfatal stroke }\end{array}$ & $\begin{array}{l}20 \% \text { risk reduction in a 4-step } \\
\text { analysis }(p=0.008)\end{array}$ \\
\hline $\begin{array}{l}\text { Effect of } n \text {-3 polyunsaturated } \\
\text { fatty acids in patients with } \\
\text { chronic heart failure } \\
\text { (the GISSI-HF trial): } \\
\text { a randomised, double-blind, } \\
\text { placebo-controlled trial }{ }^{(44)}\end{array}$ & $\begin{array}{l}6,975 \text { patients diagnosed with } \\
\text { NYHA class II-IV heart failure }\end{array}$ & $\begin{array}{c}\text { Supplementation with n-3 PUFA } \\
\text { (1 g daily, a capsule containing } \\
850-882 \mathrm{mg} \text { EPA and DHA } \\
\text { at } 1: 2)\end{array}$ & $\begin{array}{l}\text { Cardiovascular death } \\
\text { or hospital admission }\end{array}$ & $\begin{array}{l}57 \% \text { of patients on n-3 PUFA } \\
\text { vs. } 59 \% \text { of patients on placebo } \\
\text { (RR }=0.92 ; 95 \% \\
\text { Cl } 0.849-0.999 \text { ) }\end{array}$ \\
\hline $\begin{array}{c}\mathrm{n}-3 \text { fatty acids and } \\
\text { cardiovascular events } \\
\text { after myocardial infarction }{ }^{(45)}\end{array}$ & $\begin{array}{c}4,837 \text { patients } 60-80 \text { years } \\
\text { of age after } \mathrm{Ml}\end{array}$ & $\begin{array}{c}\text { Daily intake of margarines } \\
\text { supplemented with EPA/DHA } \\
\text { (400 mg EPA/DHA at 3:2), } \\
\text { ALA }(2 \mathrm{~g}), \text { EPA/DHA } \\
(400 \mathrm{mg} \text { EPA/DHA at } 3: 2) \\
\text { and ALA }(2 \mathrm{~g}) \text { or placebo }\end{array}$ & $\begin{array}{l}\text { Fatal or nonfatal MI } \\
\text { and cardiac interventions }\end{array}$ & $\begin{array}{c}\text { No reduction in both EPA/DHA } \\
\text { (RR 1.01; } 95 \% \text { Cl 0.87-1.17) } \\
\text { and ALA group (RR 0.91; } \\
95 \% \text { Cl 0.78-1.05) }\end{array}$ \\
\hline $\begin{array}{l}\text { n-3 fatty acids and } \\
\text { cardiovascular outcomes } \\
\text { in patients with dysglycemia }{ }^{(46)}\end{array}$ & $\begin{array}{l}12,536 \text { patients at high } \\
\text { cardiovascular risk and abnormal } \\
\text { glucose tolerance, fasting blood } \\
\text { glucose or diabetes mellitus }\end{array}$ & $\begin{array}{l}\text { Supplementation with n-3 PUFA } \\
\text { (1 g daily, a capsule containing } \\
465 \mathrm{mg} \text { EPA and } 375 \mathrm{mg} \mathrm{DHA})\end{array}$ & Cardiovascular death & $\begin{array}{l}9.1 \% \text { in placebo group } \\
\text { vs. } 9.3 \% \text { in n-3 PUFA group } \\
\text { (RR 0.98; } 95 \% \text { Cl } 0.87-1.10 \text { ) }\end{array}$ \\
\hline $\begin{array}{l}\text { Marine } n-3 \text { fatty acids and } \\
\text { prevention of cardiovascular } \\
\text { disease and cancer }{ }^{(47)}\end{array}$ & $\begin{array}{l}25,871 \text { patients with primary } \\
\text { or secondary prevention } \\
\text { of cardiovascular diseases } \\
\text { and malignancies: } \\
\text { men aged } \geq 50 \text { years and } \\
\text { women aged } \geq 55 \text { years }\end{array}$ & $\begin{array}{l}\text { Supplementation with n-3 PUFA } \\
\text { (1 g daily, a capsule containing } \\
840 \mathrm{mg} \text { n-3 PUFA, including } \\
460 \mathrm{mg} \text { EPA and } 380 \mathrm{mg} \text { DHA) } \\
\text { and vitamin D (2000 IU daily) }\end{array}$ & $\begin{array}{c}\text { MI, stroke } \\
\text { or cardiovascular death }\end{array}$ & $\begin{array}{c}\text { No reduction } \\
\text { (RR 0.92;95\% Cl 0.80-1.06) }\end{array}$ \\
\hline $\begin{array}{l}\text { Effects of eicosapentaenoic } \\
\text { acid on major coronary events } \\
\text { in hypercholesterolaemic } \\
\text { patients (JELLS): a randomised } \\
\text { open-label, blinded endpoint } \\
\text { analysis }{ }^{(48)}\end{array}$ & $\begin{array}{l}18,645 \text { patients with total } \\
\text { cholesterol } \geq 6.5 \mathrm{mmol} / \mathrm{L}\end{array}$ & $\begin{array}{l}\text { Supplementation with EPA } \\
\text { (1800 mg daily })\end{array}$ & $\begin{array}{l}\text { Sudden cardiac death, fatal and } \\
\text { nonfatal MI, and other nonfatal } \\
\text { events such as unstable angina, } \\
\text { angioplasty, coronary stenting } \\
\text { or bypass surgery }\end{array}$ & $\begin{array}{l}19 \% \text { reduction } \\
(p=0.001)\end{array}$ \\
\hline $\begin{array}{l}\text { Cardiovascular risk reduction } \\
\text { with icosapent ethyl for } \\
\text { hypertriglyceridemia }^{(49)}\end{array}$ & $\begin{array}{l}\text { 8,179 patients with established } \\
\text { CVD or diabetes and other risk } \\
\text { factors, with well-controlled } \\
\text { LDL cholesterol on statins and } \\
\text { elevated baseline triglycerides }\end{array}$ & $\begin{array}{l}\text { Supplementation with EPA } \\
(2 \times 2 \mathrm{~g} \text { daily })\end{array}$ & $\begin{array}{l}\text { Cardiovascular death, nonfatal } \\
\text { Ml, nonfatal stroke, coronary } \\
\text { revascularisation, or unstable } \\
\text { angina }\end{array}$ & $\begin{array}{c}25 \% \text { reduction } \\
\text { (RR } 0.75 ; 95 \% \mathrm{Cl} 0.68-0.83 \text { ) }\end{array}$ \\
\hline
\end{tabular}

Tab. 1. A summary of clinical trials assessing the effects of omega-3 fatty acids on the cardiovascular risk

clarified yet. Also, some aspects of their multidirectional mechanism of action remain unclear, but they undoubtedly have an inhibitory effect on the pathological pathways in cardiovascular diseases. The issue is additionally complicated by the occasional reports on new aspects of the impact of omega- 3 fatty acids on the human body. Until the publication of REDUCE-IT, the effectiveness of omega-3 fatty acids in clinical trials was in most cases (except for the GISSI-Prevenzione trial and the JELIS trial) disappointing and failed to meet the expectations resulting mainly from observational studies in the population whose diet was rich in fish-derived omega-3 fatty acids. However, if their effectiveness, especially at a higher dose, is confirmed in further clinical trials, it will be a very promising prospect in the treatment of cardiovascular diseases as part of both primary and secondary prevention. It is worth mentioning here the advantage of omega- 3 fatty acids contained in pharmaceutical preparations over those derived from fish. Sea fish are well-known to contain small amounts of heavy metals. Increased consumption of fish automatically increases the intake of these toxic compounds. They accumulate in the body, which at some point can disturb the homeostasis. It is also very important that the presented clinical trials found no significant adverse effects that could force patients to discontinue therapy or to choose a different therapeutic option already at baseline. Based on the current literature, it should be mentioned that preparations containing omega- 3 fatty acids must be used in therapeutic rather than supplementary doses, i.e. $1.8 \mathrm{~g}$ for esters and $4 \mathrm{~g}$ in the case of a combination of omega-3 fatty acids, in order to have a clinically detectable effect. In dietary supplements, these doses usually are 100-150 mg of EPA and/or DHA. It seems that when combined with standard therapy and other modern treatments for use in cardiovascular diseases, such as, for example, acyl-CoA acyltransferase inhibitors:cholesterol, acyl-CoA acyltransferase inhibitors:diacylglycerol 1 or antisense oligonucleotides, omega-3 fatty acids may be an important therapeutic option for patients at increased cardiovascular risk, especially in secondary prevention.

\section{Conflict of interest}

The authors do not report any financial or personal connections with other persons or organisations, which might negatively affect the contents of this publication and/or claim authorship rights to this publication. 


\section{References}

1. Roth GA, Johnson C, Abajobir A et al.: Global, regional, and national burden of cardiovascular diseases for 10 causes, 1990 to 2015. J Am Coll Cardiol 2017; 70: 1-25.

2. Okopień B, Bułdak $€$, Bołdys A: Benefits and risks of the treatment with fibrates - a comprehensive summary. Expert Rev Clin Pharmacol 2018; 11: 1099-1112.

3. Bang HO, Dyerberg J, Hjøorne N: The composition of food consumed by Greenland Eskimos. Acta Med Scand 1976; 200: 69-73.

4. Grupa Robocza do spraw leczenia dyslipidemii Europejskiego Towarzystwa Kardiologicznego (ESC) oraz Europejskiego Towarzystwa Badań nad Miażdżyca (EAS): Wytyczne ESC/EAS dotyczące postępowania w dyslipidemiach: jak dzięki leczeniu zaburzeń lipidowych obniżyć ryzyko sercowo-naczyniowe (2019). Available from: https://www.mp.pl/kardiologiapolska/static/pdf/ KP-Wytyczne_dyslipidemie.pdf.

5. Botham KM, Mayes PA: Lipidy o znaczeniu fizjologicznym. In: Rodwell VW, Bender DA, Botham KM et al. (eds.): Biochemia Harpera ilustrowana. $7^{\text {th }}$ ed., Wydawnictwo Lekarskie PZWL, Warszawa 2018: 263-354.

6. Bannenberg G, Serhan CN: Specialized pro-resolving lipid mediators in the inflammatory response: an update. Biochim Biophys Acta 2010; 1801: 1260-1273.

7. Arterburn LM, Hall EB, Oken H: Distribution, interconversion, and dose response of n-3 fatty acids in humans. Am J Clin Nutr 2006; 83 Suppl 6: 1467S-1476S.

8. Simopoulos AP: The omega-6/omega- 3 fatty acid ratio, genetic variation, and cardiovascular disease. Asia Pac J Clin Nutr 2008; 17 Suppl 1: 131-134.

9. Patterson E, Wall R, Fitzgerald GF et al.: Health implications of high dietary omega- 6 polyunsaturated fatty acids. J Nutr Metab 2012; 2012: 539426.

10. Simopoulos AP: An increase in the omega-6/omega- 3 fatty acid ratio increases the risk for obesity. Nutrients 2016; 8: 128.

11. Mason RP, Jacob RF, Shrivastava $S$ et al.: Eicosapentaenoic acid reduces membrane fluidity, inhibits cholesterol domain formation, and normalizes bilayer width in atherosclerotic-like model membranes. Biochim Biophys Acta 2016; 1858: 3131-3140.

12. Ma DWL, Seo J, Switzer KC et al.: n-3 PUFA and membrane microdomains: a new frontier in bioactive lipid research. J Nutr Biochem 2004; 15: 700-706.

13. Mizia-Stec K, Haberka M: Układ sercowo-naczyniowy. In: Zahorska-Markiewicz B, Małecka-Tendera E, Olszanecka-Glinianowicz $\mathrm{M}$ et al. (eds.): Patofizjologia kliniczna. $2^{\text {nd }}$ ed., Edra Urban \& Partner, Wrocław 2017: 103-166.

14. Ridker PM, Everett BM, Thuren T et al.; CANTOS Trial Group: Antiinflammatory therapy with canakinumab for atherosclerotic disease. N Engl J Med 2017; 377: 1119-1131.

15. Simopoulos AP: Omega- 3 fatty acids in inflammation and autoimmune diseases. J Am Coll Nutr 2002; 21: 495-505.

16. Zhang MJ, Spite M: Resolvins: anti-inflammatory and proresolving mediators derived from omega-3 polyunsaturated fatty acids. Annu Rev Nutr 2012; 32: 203-227.

17. Puglisi MJ, Hasty AH, Saraswathi V: The role of adipose tissue in mediating the beneficial effects of dietary fish oil. J Nutr Biochem 2011; 22: 101-108.

18. Satoh-Asahara N, Shimatsu A, Sasaki Y et al.: Highly purified eicosapentaenoic acid increases interleukin-10 levels of peripheral blood monocytes in obese patients with dyslipidemia. Diabetes Care 2012; 35: 2631-2639.

19. Zhao YT, Shao L, Teng LL et al.: Effects of $n-3$ polyunsaturated fatty acid therapy on plasma inflammatory markers and N-terminal pro-brain natriuretic peptide in elderly patients with chronic heart failure. J Int Med Res 2009; 37: 1831-1841.

20. Kiecolt-Glaser JK, Belury MA, Andridge R et al.: Omega-3 supplementation lowers inflammation in healthy middle-aged and older adults: a randomized controlled trial. Brain Behav Immun 2012; 26: 988-995.
21. Schmidt EB, Pedersen JO, Varming K et al.: n-3 fatty acids and leukocyte chemotaxis. Effects in hyperlipidemia and dose-response studies in healthy men. Arterioscler Thromb 1991; 11: 429-435.

22. Baker EJ, Yusof MH, Yaqoob P et al.: Omega-3 fatty acids and leukocyte-endothelium adhesion: novel anti-atherosclerotic actions. Mol Aspects Med 2018; 64: 169-181.

23. Kjeldsen SE: Hypertension and cardiovascular risk: general aspects. Pharmacol Res 2018; 129: 95-99.

24. Colussi G, Catena C, Novello M et al.: Impact of omega-3 polyunsaturated fatty acids on vascular function and blood pressure: relevance for cardiovascular outcomes. Nutr Metab Cardiovasc Dis 2017; 27: 191-200.

25. Borghi C, Cicero AFG: Omega-3 polyunsaturated fatty acids: their potential role in blood pressure prevention and management. Heart Int 2006; 2: 98

26. Calvo MJ, Martínez MS, Torres W et al.: Omega-3 polyunsaturated fatty acids and cardiovascular health: a molecular view into structure and function. Vessel Plus 2017; 1: 116-128.

27. Larson MK, Tormoen GW, Weaver LJ et al.: Exogenous modification of platelet membranes with the omega-3 fatty acids EPA and DHA reduces platelet procoagulant activity and thrombus formation. Am J Physiol Cell Physiol 2013; 304: C273-C279.

28. Gajos G, Rostoff P, Undas A et al.: Effects of polyunsaturated omega-3 fatty acids on responsiveness to dual antiplatelet therapy in patients undergoing percutaneous coronary intervention: the OMEGA-PCI (OMEGA-3 fatty acids after PCI to modify responsiveness to dual antiplatelet therapy) study. J Am Coll Cardiol 2010; 55: 1671-1678.

29. Leaf A, Kang JX, Xiao YF et al.: Clinical prevention of sudden cardiac death by $n-3$ polyunsaturated fatty acids and mechanism of prevention of arrhythmias by n-3 fish oils. Circulation 2003; 107: 2646-2652.

30. Christensen JH, Schmidt EB: Autonomic nervous system, heart rate variability and n-3 fatty acids. J Cardiovasc Med (Hagerstown) 2007; 8 Suppl 1: S19-S22.

31. Moertl D, Hammer A, Steiner S et al.: Dose-dependent effects of omega-3-polyunsaturated fatty acids on systolic left ventricular function, endothelial function, and markers of inflammation in chronic heart failure of nonischemic origin: a double-blind, placebo-controlled, 3-arm study. Am Heart J 2011; 161: 915.e1-915.e9.

32. Oikonomou E, Vogiatzi G, Karlis D et al.: Effects of omega-3 polyunsaturated fatty acids on fibrosis, endothelial function and myocardial performance, in ischemic heart failure patients. Clin Nutr 2019; 38: 1188-1197.

33. Nichols GA, Philip S, Reynolds K et al.: Increased cardiovascular risk in hypertriglyceridemic patients with statin-controlled LDL cholesterol. J Clin Endocrinol Metab 2018; 103: 3019-3027.

34. Ganda OP, Bhatt DL, Mason RP et al.: Unmet need for adjunctive dyslipidemia therapy in hypertriglyceridemia management. J Am Coll Cardiol 2018; 72: 330-343.

35. Balk EM, Lichtenstein AH, Chung $M$ et al.: Effects of omega-3 fatty acids on serum markers of cardiovascular disease risk: a systematic review. Atherosclerosis 2006; 189: 19-30.

36. Kastelein JJP, Maki KC, Susekov A et al.: Omega-3 free fatty acids for the treatment of severe hypertriglyceridemia: the EpanoVa fOr Lowering Very high triglyceridEs (EVOLVE) trial. J Clin Lipidol 2014; 8: 94-106.

37. Bays HE, Tighe AP, Sadovsky R et al.: Prescription omega- 3 fatty acids and their lipid effects: physiologic mechanisms of action and clinical implications. Expert Rev Cardiovasc Ther 2008; 6: 391-409.

38. Jacobson TA, Glickstein SB, Rowe JD et al.: Effects of eicosapentaenoic acid and docosahexaenoic acid on low-density lipoprotein cholesterol and other lipids: a review. J Clin Lipidol 2012; 6: 5-18.

39. Pizzini A, Lunger L, Demetz $E$ et al.: The role of omega- 3 fatty acids in reverse cholesterol transport: a review. Nutrients 2017; 9: 1099.

40. Zhang Y, Zhuang P, He W et al.: Association of fish and longchain omega-3 fatty acids intakes with total and cause-specific mortality: prospective analysis of 421309 individuals. J Intern Med 2018; 284: 399-417. 
41. Rees K, Takeda A, Martin $\mathrm{N}$ et al.: Mediterranean-style diet for the primary and secondary prevention of cardiovascular disease. Cochrane Database Syst Rev 2019; 3: CD009825.

42. Jayedi A, Shab-Bidar S, Eimeri S et al.: Fish consumption and risk of all-cause and cardiovascular mortality: a dose-response meta-analysis of prospective observational studies. Public Health Nutr 2018; 21: 1297-1306.

43. Dietary supplementation with $n-3$ polyunsaturated fatty acids and vitamin $\mathrm{E}$ after myocardial infarction: results of the GISSIPrevenzione trial. Gruppo Italiano per lo Studio della Sopravvivenza nell'Infarto miocardico. Lancet 1999; 354: 447-455. Erratum in: Lancet 2001; 357: 642. Erratum in: Lancet 2007; 369: 106.

44. Tavazzi L, Maggioni AP, Marchioli R et al.; GISSI-HF Investigators: Effect of $\mathrm{n}-3$ polyunsaturated fatty acids in patients with chronic heart failure (the GISSI-HF trial): a randomised, doubleblind, placebo-controlled trial. Lancet 2008; 372: 1223-1230.

45. Kromhout D, Giltay EJ, Geleijnse JM; Alpha Omega Trial Group: n-3 fatty acids and cardiovascular events after myocardial infarction. N Engl J Med 2010; 363: 2015-2026.

46. ORIGIN Trial Investigators; Bosch J, Gerstein HC, Dagenais GR et al.: n-3 fatty acids and cardiovascular outcomes in patients with dysglycemia. N Engl J Med 2012; 367: 309-318.

47. Manson JE, Cook NR, Lee IM et al.; VITAL Research Group: Marine n-3 fatty acids and prevention of cardiovascular disease and cancer. N Engl J Med 2019; 380: 23-32.
48. Yokoyama M, Origasa H, Matsuzaki M et al.; Japan EPA lipid intervention study (JELIS) Investigators: Effects of eicosapentaenoic acid on major coronary events in hypercholesterolaemic patients (JELIS): a randomised open-label, blinded endpoint analysis. Lancet 2007; 369: 1090-1098. Erratum in: Lancet 2007; 370: 220.

49. Bhatt DL, Steg PG, Miller M et al.; REDUCE-IT Investigators: Cardiovascular risk reduction with icosapent ethyl for hypertriglyceridemia. N Engl J Med 2019; 380: 11-22.

50. Aung T, Halsey J, Kromhout D et al.; Omega-3 Treatment Trialists' Collaboration: Associations of omega-3 fatty acid supplement use with cardiovascular disease risks: meta-analysis of 10 trials involving 77917 individuals. JAMA Cardiol 2018; 3: 225-234.

51. Abdelhamid AS, Brown TJ, Brainard JS et al.: Omega-3 fatty acids for the primary and secondary prevention of cardiovascular disease. Cochrane Database Syst Rev 2018; 7: CD003177.

52. Hu Y, Hu FB, Manson JE: Marine omega- 3 supplementation and cardiovascular disease: an updated meta-analysis of 13 randomized controlled trials involving 127477 participants. J Am Heart Assoc 2019; 8: e013543. 